\title{
MODERASI KOMITMEN ORGANISASI TERHADAP HUBUNGAN ANTARA PARTISIPASI ANGGARAN DENGAN KINERJA MANEJERIAL DI KABUPATEN HALMAHERA BARAT
}

\author{
Yustiana Djaelani ${ }^{1}$, Subhan ${ }^{1}$ \\ ${ }^{1}$ Dosen Jurusan Akuntansi Fakultas Ekonomi Universitas Khairun Ternate
}

\begin{abstract}
This study examines the effect of budgetary participation on managerial performance with organizational commitment as a moderating variable. The purpose of the study was to find empirical evidences about the relationship and positive and significant influence between budgetary participation and managerial performance, and organizational commitment can be a moderation of the relationship between budgetary participation and managerial performance. The study respondents were budget compilers in SKPD in West Halmahera Regency, with a sample of 64 respondents. Data collection with a list of questions adopted from previous researchers. The collected data is processed using moderating regression analysis (MRA) and regression interactions between variables. The results of the study are (1) there is a significant influence and positive relationship between budgetary participation and managerial performance; and (2) there is no influence of organizational commitment on the relationship of budgetary participation and managerial performance.
\end{abstract}

Keywords: Budget Participation, Organizational Commitment, Managerial Performance

\begin{abstract}
ABSTRAK
Studi ini meneliti pengaruh partisipasi anggaran terhadap kinerja manajerial dengan komitmen organisasi sebagai variabel moderasi. Tujuan penelitian adalah untuk menemukan bukti empiris tentang hubungan dan pengaruh posistif dan signifikan antara partisipasi anggaran dan kinerja manajerial, dan komitmen organisasi dapat menjadi moderasi hubungan antara partisipasi anggaran dan kinerja manajerial. Responden penelitian ini adalah penyusun anggaran pada SKPD di Kabupaten Halmahera Barat dengan total sampel adalah 64 responden. Pengumpulan data dengan daftar pertanyaan yang diadopsi dari peneliti terdahulu. Data yang dikumpulkan diolah dengan menggunakan moderating regression analysis (MRA) dan regresi interaksi antar variabel. Hasil penelitian menunjukkan (1) terdapat pengaruh dan hubungan positif yang signifikan antara partisipasi anggaran dan kinerja manajerial; dan (2) tidak terdapat pengaruh komitmen organisasi terhadap hubungan partisipasi anggaran dan kinerja manajerial.
\end{abstract}

Kata kunci: Partisipasi Anggaran, Komitmen Organisasional, Kinerja Manajerial

\author{
Jurnal Akun Nabelo: \\ Jurnal Akuntansi Netral, Akuntabel, Objektif \\ Volume 1/Nomor 2/Jan 2019 \\ Jurusan Akuntansi FE-Universitas Tadulako
}

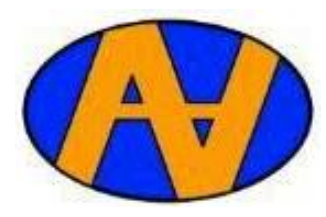




\section{A. PENDAhuluan}

Setiap organisasi, baik sektor publik maupun swasta memerlukan sistem pengendalian manajemen yang menjamin tercapainya tujuan organisasi secara efektif dan efisien. Salah satu elemen maupun indikator penting dalam sistem pengendalian manajemen adalah anggaran. Anggaran merupakan alat bantu manajemen dalam mengalokasikan keterbatasan sumber daya dan sumber dana yang dimiliki organisasi untuk mencapai tujuan. Pemahaman terhadap tujuan anggaran dan informasi tentang beberapa tujuan anggaran memberi dasar bagi manajer untuk mengukur efisiensi, mengidentifikasi masalah dan mengendalikan biaya.

Penganggaran sektor publik terkait dalam proses penentuan jumlah alokasi dana untuk tiap-tiap program dan aktivitas dalam satuan moneter. Tahap penganggaran menjadi sangat penting, karena anggaran yang tidak efektif dan tidak berorientasi pada kinerja akan dapat menggagalkan perencanaan yang telah disusun. Penyusunan anggaran yang dilakukan oleh manajer puncak sangat menentukan perilaku bawahannya sehingga dalam penyusunan anggaran diperlukan perhatian yang lebih terhadap perilaku-perilaku yang berhubungan dengan anggaran agar dapat memotivasi para manajer tingkat menengah dan bawah dalam mencapai tujuan organisasi melalui anggaran. Dengan demikian, manajer puncak akan berusaha menggunakan metode penyusunan anggaran yang lebih baik.

Perubahan paradigma anggaran daerah dilakukan untuk menghasilkan anggaran daerah yang benar-benar mencerminkan kepentingan dan pengharapan masyarakat daerah setempat terhadap pengelolaan keuangan daerah secara ekonomis, efisien, dan efektif. Reformasi anggaran daerah dimulai dengan penyusunan anggaran daerah yang tidak lagi mengacu kepada PP No. 6 tahun
1975 tentang Cara Penyusunan Anggaran Pendapatan dan Belanja Daerah, Pelaksanaan Tata Usaha Keuangan Daerah, dan Penyusunan Perhitungan Anggaran Pendapatan dan Belanja. Perubahan kebijakan tentang anggaran mengikuti perubahan kebijakan pengelolaan keuangan negara. Salah satu bentuk perubahan kebijakan tersebut dengan mulai diberlakukannya PP No. 105 tahun 2000, tentang Pengelolaan dan Pertanggungjawaban Keuangan Daerah, selanjutnya diganti dengan PP No. 58 tahun 2005 tentang Pengelolaan Keuangan Daerah, yang diikuti dengan diterbitkannya Permendagri No. 13 tahun 2006 tentang Pedoman Pengelolaan Keuangan Daerah. Peran penting anggaran dalam organisasi sektor publik berasal dari kegunaannya dalam menentukan estimasi pendapatan atau jumlah tagihan atas jasa yang diberikan (Nordiawan, 2006).

Kinerja dinilai berdasarkan pencapaian target anggaran dan efisiensi pelaksanaan anggaran. Dalam perusahaan bisnis,, pelaksana anggaran menerima kompensasi berupa bonus apabila mampu memenuhi atau melebihi target anggaran dan punishment bila tidak mampu memenuhi. Kinerja manjerial merupakan salah satu faktor yang dapat dipakai untuk meningkatkan efektivitas organisasi. Pengaruh partisipasi penganggaran pada kinerja manajerial merupakan tema yang menarik dalam penelitian akuntansi manajemen.

Beberapa penelitian telah dilakukan mengenai pengaruh partisipasi penganggaran terhadap kinerja manajerial. Menurut Rebekah dan Brown (2007), partisipasi penganggaran merupakan topik yang paling banyak dalam akuntansi manajemen. Namun, hasil penelitian terdahulu masih banyak yang tidak konsisten antara penelitian satu dengan penelitian lainnya menyebabkan keterkaitan antara partisipasi penyusunan anggaran terhadap kinerja manajerial masih merupakan 
sesuatu yang menarik untuk diteliti. Hasil penelitian tersebut dikemukakan Sumarno (2005) bahwa ada yang menunjukkan partisipasi penganggaran berpengaruh positif dan signifikan terhadap kinerja manajerial (Brownell, 1986) dalam Sumarno (2005) dan ada yang menunjukkan bahwa partisipasi penyusunan anggaran mempunyai pengaruh tidak signifikan terhadap kinerja manajerial (Milani; Brownell \& Hirst; $\&$ Morse; dan Reimer dalam Sumarno (2005)).

Penelitian ini merujuk pada penelitian Sumarno (2005) yang meneliti tentang pengaruh komitmen organisasi dan gaya kepemimpinan terhadap hubungan antara partisipasi anggaran dan kinerja manajerial. Penelitian ini berbeda dengan penelitian Sumarno (2005) dalam hal lokasi penelitian Sumarno (2005) yaitu kantor cabang perbankan Indonesia di Jakarta sedangkan dalam penelitian ini lokasi penelitian pada kantor Pemerintah Kabupaten Halmahera Barat. Selain itu, responden dalam penelitian ini adalah para pejabat struktural di Satuan Kerja Perangkat Daerah Pemerintah Kabupaten Halmahera Barat yang memiliki peran dalam proses penyusunan anggaran (RKA-SKPD) dan memiliki masa kerja minimal satu tahun dalam periode penyusunan anggaran.

\section{B. TELAAH PUSTAKA}

\section{B.1 Partisipasi Anggaran}

Menurut Robbins (2003), partisipasi merupakan suatu konsep di mana bawahan ikut terlibat dalam pengambilan keputusan sampai tingkat tertentu bersama atasannya. Sementara Brownell (1982) dalam Hafiz (2007) menyatakan bahwa partisipasi dalam penyusunan anggaran merupakan proses di mana individu terlibat dalam penyusunan target anggaran, lalu individu tersebut dievaluasi kinerjanya dan memperoleh penghargaan berdasarkan target anggaran. Ada penyusunan dengan menggunakan pendekatan partisipasi, informasi anggaran yang didapat oleh manajemen puncak, digunakan untuk mengevaluasi kinerja manajerial fungsional dan mendistribusikan penghargaan dan hukuman. Sehingga, anggaran partisipasi penting dalam memainkan peran untuk meningkatkan sikap dan kinerja manajerial. Penggunaan anggaran untuk pengendalian, evaluasi kerja, komunikasi, dan koordinasi menyiratkan untuk membawa banyak dimensi perilaku (Hansen \& Mowen, 2004).

Inti dari partisipasi anggaran adalah diperlukan kerja sama antara seluruh tingkatan organisasi. Manajer puncak biasanya kurang mengetahui bagian sehari-hari, sehingga harus mengandalkan informasi anggaran yang lebih rinci dari bawahannya. Dari sisi lain, manajer puncak mempunyai perspektif yang lebih luas atas perusahaan secara keseluruhan yang sangat vital dalam pembuata anggaran secara umum. Menurut Garrison \& Noreen (2000), setiap tingkatan tanggung jawab dalam suatu organisasi harus memberikan masukan terbaik sesuai dengan bidangnya dalam suatu sistem kerja sama penyusunan anggaran.

Indriantoro (1993) dalam Poerwati (2002) berpendapat bahwa kinerja dinyatakan efektif apabila tujuan anggaran tercapai dan bawahan mendapat kesempatan terlibat dan berpartisipasi dalam proses penyusunan anggaran serta memotivasi bawahan mengidentifikasi dan melakukan negoisasi dengan atasan mengenai target anggaran, menerima kesepakatan anggaran dan melaksanakannya sehingga dapat menghindarkan dampak negatif anggaran yaitu faktor kriteria kinerja, sistem penghargaan (reward), dan konflik.

Keuntungan dari partisipasi adalah memacu peningkatan moral dan inisiatif bagi mereka untuk mengembangkan ide dan informasi pada seluruh tingkat manajemen, meningkatkan group cohesiveness yang kemudian meningkatkan 
kerjasama antar individu dalam pencapaian tujuan, terbentuknya group internalization yaitu penyatuan tujuan individu dan organisasi, menghindari tekanan dan kebingungan dalam melaksanakan pekerjaan dan manajer menjadi tanggap terhadap masalah-masalah sub unit tertentu serta memiliki pemahaman yang lebih baik tentang ketergantungan antar departemen.

Garrison \& Noreen (2000) menyatakan bahwa keunggulan partisipasi adalah menghargai pendapat dan pandangan tingkat menengah dan bawah sehingga mereka lebih cenderung terdorong untuk mencapai anggaran.Selain itu, dalam penganggaran partisipasi terdapat sistem kendali yang unik, yaitu kesalahan dan tanggung jawab terdapat pada penyusun anggaran itu sendiri sehingga mereka tidak dapat berdalih bahwa anggarannya tidak masuk akal untuk dicapai. Sementara Anthony \& Govindarajan (2005) menyatakan bahwa penganggaran partisipasi memiliki dua keunggulan yaitu:

1. Tujuan anggaran akan dapat lebih mudah diterima apabila anggaran tersebut berada dibawah pengawasan manajer.

2. Penganggaran partisipasi menghasilkan pertukaran informasi yang efektif antara pembuat anggaran dan pelaksana anggaran yang dekat dengan produk dan pasar.

\section{B.2. Komitmen Organisasi}

Komitmen organisasi merupakan tingkat sampai sejauh mana seorang karyawan memihak pada suatu organisasi tertentu dan tujuan-tujuannya serta berniat untuk mempertahankan keanggotaannya dalam organisasi itu. Komitmen organisasi juga merupakan nilai personal yang kadang-kadang mengacu pada sikap loyal pada perusahaan atau komitmen pada perusahaan. Seringkali komitmen organisasional diartikan secara individu dan berhubungan dengan keterlibatan orang tersebut pada organisasi tersebut. Komitmen karyawan pada organisasi merupakan salah satu sikap yang mencerminkan perasaan suka atau tidak suka seorang karyawan terhadap organisasi tempat dia bekerja (Ikhsan, 2005).

Komitmen organisasi terdiri atas tiga hal yaitu, keyakinan kuat dalam menerima nilai-nilai dan tujuan-tujuan organisasi, kemauan untuk memberikan usaha kepada organisasi, dan keinginan kuat untuk memperbaiki perannya sebagai anggota organisasi tersebut. Komitmen organisasi sebagai dorongan dari dalam diri individu untuk berbuat sesuatu agar dapat menunjang keberhasilan organisasi sesuai dengan tujuan dan lebih mengutamakan kepentingan organisasi dibandingkan kepentingan sendiri. Tiga karakteristik yang berhubungan dengan komitmen organisasi menurut Cherrington dalam Ikhsan (2005) sebagai berikut:

1. Keyakinan dan penerimaan yang kuat terhadap nilai dan tujuan perusahaan.

2. Kemauan untuk sekuat tenaga melakukan yang diperlukan untuk kepentingan organisasi.

3. Keinginan yang kuat untuk menjaga keanggotaan dalam organisasi.

Komitmen anggota organisasi menjadi penting bagi sebuah organisasi dalam menciptakan kelangsungan hidup sebuah organisasi apapun bentuk organisasinya. Komitmen menunjukkan hasrat karyawan sebuah perusahaan untuk tetap tinggal dan bekerja serta mengabdikan diri bagi perusahaan. Komitmen menguatkan kemauan karyawan dalam melaksanakan kewajiban pekerjaannya dengan sebaik-baiknya, bukan untuk kepentingan dirinya sendiri tetapi untuk pelanggan dan organisasi.

\section{B.3. Kinerja Manajerial}

Menurut Mangkunegara (2000), kinerja adalah hasil kerja secara kualitas dan kuantitas yang dicapai oleh seorang pegawai dalam melaksanakan tugasnya sesuai dengan tanggung jawab yang diberikan kepadanya. Sementara 
itu, Hasibuan (1997) dalam Hafiz (2007) mengatakan kinerja adalah suatu hasil kerja yang dicapai seseorang dalam melakasanakan tugas-tugas yang dibebankan kepadanya yang didasarkan atas kecakapan, pengalaman, dan kesungguhan serta waktu. Simamora (2000) mengemukakan kinerja karyawan adalah tingkat terhadap mana para karyawan mencapai persyaratan-persyaratan pekerjaan. Penilaian kinerja pada umumnya mencakup baik aspek kualitatif maupun kuantitatif dari pelaksanaan pekerjaan.

Berdasarkan definisi di atas maka dapat disimpulkan bahwa kinerja adalah suatu upaya dalam melaksanakan tugas, sehingga sasaran yang diinginkan dapat tercapai berdasarkan atas kemampuan yang dimiliki karyawan atas masalah yang dihadapi pada saat melaksanakan pekerjaan. Dalam mencapai sasaran atas peningkatan kinerja maka diperlukan suatu pertimbangan atas faktor-faktor yang dapat mempengaruhi masalah tersebut. Hal ini penting sebagi titik tolak dari suatu pelaksanaan konsep dalam usaha meningkatkan kinerja.

\section{B.4. Kerangka Konseptual}

Menurut Mulyadi (2001), anggaran merupakan pernyataan mengenai apa yang diharapkan, direncanakan atau diperkirakan terjadi dalam periode tertentu pada masa yang akan datang. Anggaran sebagi suatu rencana kerja yang dinyatakan secara kuantitatif, yang diukur dalam satuan moneter atau satuan lain yang mencakup jangka waktu satu tahun. Dalam penelitian ini akan dirumuskan model penelitian yang dapat menerangkan pengaruh partisipasi anggaran terhadap kinerja manajerial dengan komitmen organisasi sebagai variabel moderasi.

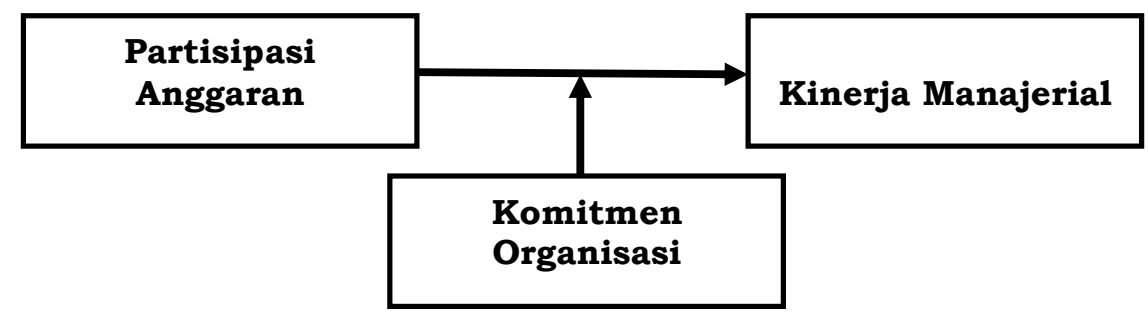

Gambar 1

Model Penelitian

\section{B.5. Pengembangan Hipotesis}

$\begin{array}{lrr}\text { B.5.1. } & \text { Pengaruh } & \text { Partisipasi } \\ \text { Anggaran } & \text { terhada } & \text { Kinerja }\end{array}$ Manajerial

Proses penyusunan anggaran merupakan kegiatan yang penting dan melibatkan berbagai pihak. Agar pelaksanaannya berjalan efektif, para pelaksana hendaknya berpartisipasi untuk merencanakan anggaran dan mengusahakan agar anggaran dapat tercapai. Tetapi yang lebih penting adalah sejauh mana tingkat partisipasi atau peran serta dalam penyiapan anggaran, karena sebenarnya anggaran yang disetujui pada dasarnya selalu menggambarkan suatu kesepakatan bersama dari banyak orang di dalam suatu organisasi atau perusahaan. Partisipasi merupakan suatu proses di mana individuindividu terlibat langsung didalamnya dan mempunyai pengaruh pada penyusunan target anggaran yang kinerjanya akan dievaluasi dan kemungkinan akan dihargai atas dasar tercapainya target anggaran mereka. Sedangkan kinerja merupakan evaluasi terhadap pekerjaan yang dilakukan lewat atasan langsung, teman, dirinya sendiri, dan bawahan.

Menurut Indriantoro \& Supomo (1998), kinerja dinyatakan efektif apabila tujuan anggaran tercapai dan bawahan mendapat kesempatan terlibat atau berpartisipasi dalam proses penyusunan anggaran serta memotivasi bawahan, mengidentifikasi dan melakukan 
negosiasi dengan atasan mengenai target anggaran, menerima kesepakatan anggaran, dan melaksanakannya sehingga dapat menghindarkan dampak negatif anggaran yaitu faktor kriteria kinerja, sistem penghargaan (reward) dan konflik. Puspaningsih (2002) menguji pengaruh partisipasi anggaran terhadap kepuasan kerja dan kinerja manajer. Partisipasi dalam penyusunan anggaran memberikan pengaruh terhadap kepuasan kerja dan kinerja manajer. Berdasarkan argumentasi di atas, dirumuskan hipotesis sebagai berikut:

H1: Partisipasi anggaran berpengaruh signifikan terhadap kinerja manajerial.

B.5.2. Pengaruh Komitmen Organisasi terhadap Hubungan antara Partisipasi Anggaran dan Kinerja Manajerial

Komitmen organisasi merupakan tingkat sampai sejauh mana seorang karyawan memihak pada suatu organisasi tertentu dan tujuan-tujuannya serta berniat untuk mempertahankan keanggotaannya dalam organisasi itu. Komitmen organisasi juga merupakan nilai personal yang kadang-kadang mengacu pada sikap loyal pada perusahaan atau komitmen pada perusahaan. Seringkali komitmen organisasional diartikan secara individu dan berhubungan dengan keterlibatan orang tersebut pada organisasi tersebut. Komitmen karyawan pada organisasi merupakan salah satu sikap yang mencerminkan perasaan suka atau tidak suka seorang karyawan terhadap organisasi tempat dia bekerja (Ikhsan, 2005). Sumarno (2005) meneliti pengaruh komitmen organisasi dan gaya kepemimpinan terhadap hubungan antara partisipasi anggaran dan kinerja manajerial. Data yang dikumpulkan diolah dengan menggunakan moderating regression analysis (MRA) dan regresi interaksi antar variabel. Hasil penelitiannya adalah terdapat pengaruh dan hubungan negatif yang signifikan antara kinerja manajerial dan partisipasi anggaran, pengaruh komitmen organisasi terhadap hubungan kinerja manajerial dan partisipasi anggaran adalah positif dan signifikan, dan tidak terdapat pengaruh antara gaya kepemimpinan terhadap hubungan antara partisipiasi anggaran dan kinerja manajerial.

$\begin{array}{llr}\text { H2: } \quad \text { Komitmen } & \text { organisasi } \\ \text { mempunyai } & \text { pengaruh } & \text { terhadap } \\ \text { hubungan } & \text { antara } & \text { partisipasi } \\ \text { anggaran } & \text { dengan } & \text { kinerja } \\ \text { manajerial. } & & \end{array}$

\section{METODE PENELITIAN}

Populasi dalam penelitian ini adalah pengelola unit kerja atau pejabat struktural pada Satuan Kerja Perangkat Daerah Pemerintah Kabupaten Halmahera Barat. Pemilihan Satuan Kerja Perangkat Daerah (SKPD) dalam penelitian ini karena SKPD termasuk dalam organisasi sektor publik yang memiliki sistem anggaran partisipatif.

Pemilihan sampel dalam penelitian ini didasarkan pada purposive sampling. Sampel dipilih berdasarkan kriteria tertentu sehingga dapat mendukung penelitian ini. Kriteria pemilihan sampel adalah sebagai berikut:

1. Pejabat struktural dan pegawai yang telah berpengalaman dalam penyusunan anggaran di Satuan Kerja Perangkat Daerah Pemerintah Kabupaten Halmahera Barat yang memiliki peran dalam proses penyusunan anggaran (RKA-SKPD) dan telah bekerja selama satu tahun dan telah memiliki pengalaman dalam penyusunan anggaran.

2. SKPD yang dijadikan sampel adalah SKPD yang berhubungan dengan penyusunan anggaran.

Sampel yang dipilih dalam penelitian ini yakni sebanyak 26 SKPD yang terkait dengan penyusunan anggaran.

Data yang digunakan dalam penelitian ini adalah data kualitatif merupakan data yang berbentuk data, kalimat, skema, dan gambar (Sugiyono, 2008). Data kualitatif yang digunakan dalam penelitian ini adalah data yang diperoleh dari 
pertanyaan kepada pegawai dan manajer pada kantor Pemerintah Daerah Kabupaten Halmahera Barat mengenai proses penyusunan anggaran yang dilakukan secara bottom up, job description, dan susunan organisasi. Perhitungan statistik penelitian ini menggunakan SPSS (Statistic Program for Social Science) versi 25.0 for Windows. Metode analisis data dimulai dari uji pendahuluan yang meliputi uji validitas dan uji reliabilitas kemudian dilakukan uji asumsi klasik. Langkah terakhir dilakukan uji analisis regresi untuk menguji hipotesis melalui alat analisis regresi linier sederahan dan regresi linier berganda untuk variabel moderasi.

\section{HASIL PENELITIAN}

\section{D.1. Profil Responden}

Jumlah kuesioner yang disebar ke masing-masing SKPD dalam lingkup pemerintah Kabupaten Halmahera Barat adalah 78 kuesioner. Kuesioner ini disebar ke 26 SKPD dengan masing-masing 3 kuesioner setiap SKPD. Dari jumlah 78 kuesioner yang disebar tersebut, 76 kuesioner dikembalikan, 1 kuesioner tidak dikembalikan, dan dari 76 kuesioner yang dikembalikan 22 kuesioner dinyatakan gugur karena data kuesioner diisi kurang lengkap maupun kesalahan pengisian kuesioner. Data kuesioner dinyatakan tidak lengkap jika ada sebagian dari kuesioner yang tidak diisi seperti umur, jenis kelamin, masa kerja, pengalaman kerja atau isi kuesioner. Sedangkan kesalahan pengisian kuesioner yaitu kesalahan dalam melingkar pilihan jawaban kuesioner. Misalnya pada pilihan jawaban 1 sampai 7 , responden memberi jawaban tidak jelas menunjukkan angka angka yang dipilih. Profil dari 64 responden yang ikut berpartisipasi dalam penelitian ini ditunjukkan dalam tabel berikut.

Tabel 1

Profil Responden

\begin{tabular}{|c|c|c|}
\hline Jenis Kelamin & Frekuensi & Persentase \\
\hline Laki-laki & 31 & $48 \%$ \\
\hline Wanita & 33 & $52 \%$ \\
\hline Jumlah & 64 & $100 \%$ \\
\hline
\end{tabular}

\begin{tabular}{|c|c|c|}
\hline Kelompok Umur & Frekuensi & Persentase \\
\hline $20-29$ & 19 & $30 \%$ \\
\hline $30-39$ & 32 & $50 \%$ \\
\hline $40-49$ & 11 & $17 \%$ \\
\hline di atas 50 & 2 & $3 \%$ \\
\hline Jumlah & 64 & $100 \%$ \\
\hline
\end{tabular}

\begin{tabular}{|c|c|c|}
\hline Masa Kerja & Frekuensi & Persentase \\
\hline di bawah 10 tahun & 31 & $48 \%$ \\
\hline $11-20$ & 30 & $47 \%$ \\
\hline di atas 20 tahun & 3 & $5 \%$ \\
\hline Jumlah & 64 & $100 \%$ \\
\hline
\end{tabular}

\begin{tabular}{|c|c|c|}
\hline Pengalaman & Frekuensi & Persentase \\
\hline di bawah 3 tahun & 42 & $66 \%$ \\
\hline $3-6$ & 18 & $28 \%$ \\
\hline di atas 6 tahun & 4 & $6 \%$ \\
\hline Jumlah & 64 & $100 \%$ \\
\hline
\end{tabular}

Sumber: Data primer diolah, 2019

Berdasarkan tabel di atas terlihat bahwa jumlah responden dalam penelitian ini baik laki-laki maupun wanita tidak terlalu berbeda jauh. 
Responden pegawai Laki-laki yaitu sebanyak 31 orang atau sebanyak $48 \%$ dari total responden sedangkan responden yang berjenis kelamin wanita sebanyak 33 orang atau sebanyak $52 \%$ dari keseluruhan responden atau berbeda $4 \%$ dari responden laki-laki. Tingkat usia responden yang paling dominan dalam penelitian ini adalah umur antara 30 sampai 39 tahun yakni sebanyak $50 \%$ atau sebanyak 32 orang dari seluruh responden. Hal ini berarti bahwa mayoritas responden yang terlibat dalam penyusunan anggaran adalah responden yang berusia 30 sampai 39 tahun. Responden yang berumur di atas 50 tahun dalam penelitian ini menjadi responden minoritas yakni 2 responden, responden 20 sampai 29 tahun sebanyak 19 responden dan umur 40 sampai 49 tahun sebanyak 11 responden.

Tabel di atas dapat diketahui bahwa rata-rata masa kerja responden di bawah 10 tahun sebanyak 31 responden atau 48\%, 10 sampai 20 tahun sebanyak 30 responden atau $47 \%$ sedangkan responden yang telah bekerja di atas 20 tahun sebanyak 3 orang atau 5 orang. Responden yang telah bekerja selama lebih 20 tahun adalah responden yang telah berumur diatas 50 tahun dan memiliki pengalaman lebih banyak dalam partisipasi penyusunan anggaran. Responden yang paling dominan dalam penyusunan anggaran dalah responden dengan pengalaman selama dibawah 3 tahun yaitu sebanyak 42 responden atau 66\%. Pengalaman menyusun anggaran selama 3 sampai 6 tahun sejumlah 18 responden dan di atas 6 tahun sebanyak 4 responden atau $6 \%$ Dari hasil ini dapat disimpulkan bahwa responden dalam penelitian ini mayoritas yang masih minim pengalaman dalam menyusun anggaran.

\section{D.2. Deskripsi Statistik}

Berdasarkan tabel statistik deskripsi dapat dilihat nilai minimum untuk partisipasi anggaran (PA) adalah 6,72 dan nilai maksimumnya adalah 29,36.
Sedangkan, mean adalah 20,8038. Hal ini berarti bahwa berdasarkan hasil deskripsi statistik tingkat partisipasi anggaran yang dilaksanakan oleh penyusun anggaran pada SKPD dalam lingkup pemerintah Kabupaten Halmahera Barat rata-rata tinggi. Standar deviasi untuk partisipasi anggaran adalah 4,44632. Hal ini berarti bahwa berdasarkan hasil statistik deskriptif terjadi perbedaan nilai partisipasi anggaran yang diteliti terhadap nilai rata-ratanya sebesar 4,44632.

Variabel kinerja manajerial memiliki nilai minimum 12,47 , nilai maksimum 34,61 dan mean 25,1961. Hal ini berarti bahwa berdasarkan statistik deskriptif tingkat kinerja manajerial yang dicapai oleh penyusun anggaran pada SKPD dalam lingkup pemerintah Kabupaten Halmahera Barat rata-rata tinggi. Sedangkan standar deviasinya adalah 5,20076. Hal ini berarti bahwa berdasarkan hasil statistik deskriptif terjadi perbedaan nilai kinerja manajerial yang diteliti terhadap nilai rataratanya sebesar 5,20076. Nilai standar deviasi lebih kecil dari pada nilai mean membuktikan bahwa simpangan data kinerja manajerial relatif baik.

Variabel komitmen organisasi memiliki nilai minimum 18,85 , nilai maksimum 38,86 dan mean adalah 30,4925. Hal ini berarti bahwa berdasarkan statistik deskriptif tingkat komitmen organisasi yang dicapai penyusun anggaran pada SKPD dalam lingkup pemerintah Kabupaten Halmahera Barat ratarata tinggi. Sedangkan standar deviasinya adalah 5,60009. Hal ini berarti bahwa berdasarkan hasil statistik deskriptif terjadi perbedaan nilai komitmen organisasi yang diteliti terhadap nilai rata-ratanya sebesar 5,60009.

Berdasarkan statistik deskritif diperoleh nilai minimum dari interaksi antara partisipasi anggaran dengan komitmen organisasi sebesar 234,47, nilai maksimumnya adalah 1140,81 dan meannya adalah 6,1523 . Sedangkan standar deviasinya adalah 
206,14417. Hal ini berarti bahwa berdasarkan hasil statistik deskriptif terjadi perbedaan nilai interaksi partisipasi anggaran dengan komitmen organisasi yang diteliti dengan nilai rata-ratanya sebesar 206, 14417 .

Tabel 2

Deskripsi Statistik

\begin{tabular}{|l|l|l|l|l|l|}
\hline Variabel & $\mathrm{N}$ & Minimum & Maximum & Mean & Std. Deviation \\
\hline PA & 64 & 6.72 & 29.36 & 20.8038 & 4.44632 \\
KO & 64 & 18.85 & 38.86 & 30.4925 & 5.60009 \\
KM & 64 & 12.47 & 34.61 & 25.1961 & 5.20076 \\
PA_KO & 64 & 234.47 & 1140.81 & $6.1523 \mathrm{E} 2$ & 206.14417 \\
Valid N (listwise) & 64 & & & & \\
\hline
\end{tabular}

Sumber: Data primer diolah, 2019

\section{D.3. Hasil Pengujian Hipotesis}

Hipotesis pertama diuji dengan menggunakan analisis regresi linear sederhana. Adapun hasil pengujian ini dapat dilihat pada tabel berikut.

Tabel 3

Uji Regresi Linier Sederhana

\begin{tabular}{|c|c|c|c|c|c|}
\hline \multirow[b]{2}{*}{ Model } & \multicolumn{2}{|c|}{$\begin{array}{l}\text { Unstandardized } \\
\text { Coefficients }\end{array}$} & \multirow{2}{*}{$\begin{array}{c}\begin{array}{c}\text { Standardized } \\
\text { Coefficients }\end{array} \\
\text { Beta }\end{array}$} & \multirow[b]{2}{*}{$\mathrm{t}$} & \multirow[b]{2}{*}{ Sig. } \\
\hline & B & Std. Error & & & \\
\hline \multirow[t]{2}{*}{ (Constant) } & 17.970 & 3.017 & & 5.957 & .000 \\
\hline & .347 & .142 & .297 & 2.449 & .017 \\
\hline $\begin{array}{l}\mathrm{R} \\
\mathrm{R} \text { Square }\end{array}$ & \multicolumn{2}{|l|}{$\begin{array}{l}0.897 \\
0.788\end{array}$} & \multicolumn{2}{|c|}{$\begin{array}{l}\text { Adj. R Square } \\
\text { Std. Error }\end{array}$} & $\begin{array}{l}: 0.773 \\
: 5.00606\end{array}$ \\
\hline
\end{tabular}

a. Dependent Variable: KM

Sumber: Output SPSS, 2019

Berdasarkan tabel di atas dapat dibuat suatu model persamaan regresi linear sederhana yaitu sebagai berikut:

$\mathrm{KM}=17,970+0,347 \mathrm{PA}$

Tabel di atas menunjukkan bahwa terdapat pengaruh antara partisipasi penganggaran terhadap kinerja manajerial dengan nilai $t$ hitung sebesar 2,449 dengan signifikansi sebesar 0,017 yang lebih kecil dari $a=0,05$. Hal ini berarti partisipasi anggaran berpengaruh positif dan signifikan terhadap kinerja manajerial, maka

Tabel 4

Uji Regresi Variabel Moderasi

\begin{tabular}{|c|c|c|c|c|c|c|}
\hline & \multirow[b]{2}{*}{ Model } & \multicolumn{2}{|c|}{$\begin{array}{l}\text { Unstandardized } \\
\text { Coefficients }\end{array}$} & \multirow{2}{*}{$\begin{array}{c}\begin{array}{c}\text { Standardized } \\
\text { Coefficients }\end{array} \\
\text { Beta }\end{array}$} & \multirow[b]{2}{*}{$\mathrm{t}$} & \multirow[b]{2}{*}{ Sig. } \\
\hline & & B & Std. Error & & & \\
\hline \multirow[t]{3}{*}{1} & (Constant) & 8.578 & 5.290 & & 1.621 & .110 \\
\hline & PA & .520 & .223 & .444 & 2.330 & .023 \\
\hline & $\mathrm{KO}$ & .349 & .161 & .376 & 2.170 & .034 \\
\hline
\end{tabular}

hipotesis pertama diterima. Nilai $\mathrm{R}^{2}$ pada tabel di atas adalah sebesar 0,788 . Hal ini berarti bahwa 78,8 persen variasi kinerja manajerial dapat dijelaskan oleh partisipasi anggaran, sedangkan sisanya sebesar 21,2 persen dijelaskan oleh faktor-faktor yang tidak disebutkan dalam model.

Hipotesis kedua diuji dengan menggunakan teknik Moderate Regression Analysis. Hasil uji hipotesis kedua dapat dilihat pada tabel berikut. 


\begin{tabular}{|l|l|l|l|l|r|}
\hline PA_KO & -.008 & .006 & -.312 & -1.290 & .202 \\
\hline R & $: 0.795$ & & Adj. R Square $: 0.614$ \\
R Square & $: 0.656$ & & Std. Error $\quad: 4.89479$ \\
\hline
\end{tabular}

a. Dependent Variable: KM

Sumber: Output SPSS, 2019

Berdasarkan tabel di atas dapat dibuat suatu model persamaan regresi linear sederhana yaitu sebagai berikut:

$\mathrm{KM}=8,578+0,520 \mathrm{PA}+0.349 \mathrm{KO}-$ $0,008(\mathrm{PP})(\mathrm{KO}) \ldots \ldots \ldots \ldots \ldots \ldots \ldots(2)$

Tabel di atas menunjukkan interaksi variabel partisipasi anggaran dan komitmen organisasi memiliki tingkat signifikansi 0,202 lebih besar dari $\mathrm{a}=0,05$ menandakan $\mathrm{H} 2$ ditolak. Hal ini berarti komitmen organisasi tidak mampu memoderasi hubungan antara partisipasi anggaran dan kinerja manajerial. Berdasarkan tabel di atas besarnya $\mathrm{R}^{2}$ adalah 0,656 . Ini berarti 65,6 persen variasi kinerja manajerial dapat dijelaskan oleh partisipasi anggaran dan komitmen organisasi, sedangkan sisanya sebesar 34,4 persen dijelaskan oleh faktor-faktor yang tidak disebutkan dalam model.

\section{D.4. Pembahasan}

Hasil pengujian menunjukkan bahwa partisipasi anggaran berpengaruh terhadap kinerja manajerial. Koefisien regresi bernilai (b1) positif, maka arah pengaruh partisipasi anggaran terhadap kinerja manajerial adalah positif. Hal ini berarti semakin tinggi tingkat partisipasi anggaran, semakin tinggi pula kinerja manajerial pada SKPD dalam lingkup pemerintah Kabupaten Halmahera Barat. Begitu juga sebaliknya, semakin rendah partisipasi anggaran, maka semakin rendah pula kinerja manajerial pada SKPD dalam lingkup pemerintah Kabupaten Halmahera Barat. Ini memberikan indikasi bahwa dengan adanya partisipasi anggaran akan mendorong para manajer untuk bertanggungjawab terhadap masingmasing tugas yang diembannya, sehingga dapat meningkatkan kinerjanya untuk mencapai sasaran yang ditetapkan dalam anggaran.
Partisipasi dapat meningkatkan kinerja karena partisipasi memungkinkan bawahan mengkomunikasikan apa yang mereka butuhkan kepada atasannya. Dalam penyusunan anggaran diperlukan komunikasi antara atasan dan bawahan untuk saling memberikan informasi antara satu sama lain di samping dapat memberikan kesempatan memasukkan informasi lokal, karena bawahan lebih mengetahui kondisi langsung pada bagiannya. Partisipasi dapat memungkinkan bawahan untuk memilih. Tindakan memilih tersebut dapat membangun komitmen dan dianggap sebagai tanggung jawab atas apa yang telah dipilih. Semua kelebihan partisipasi ini pada akhirnya akan meningkatkan kinerja.

Hasil penelitian ini konsisten dengan hasil penelitian yang dilakukan Puspaningsih (2002) yang menyatakan bahwa partisipasi dalam penyusunan anggaran memberikan pengaruh terhadap kepuasan kerja dan kinerja manajer. Dalam hubungan antara partisipasi dalam penyusunan anggaran dengan kepuasan kerja dan kinerja manajer, ada yang punya hubungan langsung, namun kadang juga ada variabel intervening misalnya role ambiguity atau job relevan information. Kadang terdapat juga variabel moderator, misal job difficulty, locus of control dan dimensi budaya. Hasil penelitian ini tidak konsisten dengan hasil penelitian yang dilakukan Sumarno (2005) yang menemukan bahwa terdapat pengaruh dan hubungan negatif yang signifikan antara kinerja manajerial dan partisipasi anggaran. Hasil penelitian ini juga menolak penelitian Hafiz (2007) yang menemukan bahwa partisipasi anggaran tidak berpengaruh terhadap kinerja manajerial. 
Sementara itu, hasil penelitian ini juga menunjukkan bahwa komitmen organisasi pada SKPD dalam lingkup pemerintah Kabupaten Halmahera Barat tidak mampu memoderasi hubungan antara partisipasi anggaran dan kinerja manajerial. Hal ini diduga karena walaupun seorang manajer setiap bagian memiliki tingkat komitmen organisasi yang tinggi tetapi karena adanya tekanan dari atasan dan persaingan dari rekan kerja, responden menjadi sulit untuk mengekspresikan rasa kecintaannya terhadap organisasi, sehingga komitmen organisasi tidak dapat memoderasi hubungan antara partisipasi anggaran dengan kinerja manajerial pada SKPD dalam lingkup pemerintah Kabupaten Halmahera Barat.

Komitmen organisasi terbukti tidak mampu memoderasi pengaruh partisipasi anggaran terhadap kinerja manajerial pada pada SKPD dalam lingkup pemerintah Kabupaten Halmahera Barat. Hal ini karena sebagian penyusun anggaran pada pada SKPD dalam lingkup pemerintah Kabupaten Halmahera Barat berpartisipasi dalam penyusunan anggaran bukan karena memiliki komitmen organisasi yang tinggi, tetapi karena struktur organisasi yang memaksa mereka untuk berpartisipasi atau hanya merupakan suatu tugas. Selain itu, tidak mampunyai variabel komitmen organisasi dalam memoderisasi hubungan antara partisipasi anggaran dengan kinerja manajerial mungkin disebabkan karena kurang adanya pengawasan terhadap para pejabat struktural dalam menjalankan tugas dan fungsinya serta kurangnya pemahaman dan penekanan terhadap target dan tujuan organisasi. Selain itu, pembebanan kerja pada unit kerja yang terlalu berat menyebabkan tidak optimalnya kinerja.

Partisipasi anggaran akan meningkatkan kinerja manajerial para anggota organisasi, jika atasan setingkat kepala dinas peduli dan perhatian terhadap komitmen para bawahan dalam berpartisipasi untuk menyusun anggaran. Oleh karena itu, maka tujuan sasaran anggaran dapat dicapai. Komitmen organisasi yang tinggi akan meningkatkan kinerja yang tinggi pula, sementara komitmen yang rendah dari aparat pemerintah daerah akan berimplikasi pada rendahnya kinerja komitmen untuk bertanggungjawab terhadap tujuan sasaran anggaran yang hendak dicapai.

Hasil penelitian ini konsisten dengan hasil penelitian yang dilakukan Minan (2009) yang menyatakan bahwa komitmen organisasi mempunyai pengaruh terhadap hubungan antara partisipasi anggaran dengan kinerja manajerial, namun tidak konsisten dengan hasil penelitian yang dilakukan oleh Sumarno (2005) yang menemukan bahwa komitmen organisasi berpengaruh positif dan signifikan terhadap hubungan partisipasi anggaran dan kinerja manajerial.

\section{E. PENUTUP}

Berdasarkan pembahasan di atas, maka disimpulkan:

1. Hasil uji hipotesis pertama menunjukkan bahwa hipotesis pertama diterima yang berarti bahwa partisipasi anggaran berpengaruh terhadap kinerja manajerial. Pengaruh ini bersifat searah (positif) yang artinya partisipasi dalam penyusunan anggaran dapat meningkatkan kinerja manajerial. Semakin tinggi tingkat partisipasi seorang pegawai pada saat proses penyusunan anggaran, maka semakin tinggi pula kinerja dari pegawai tersebut, begitu juga sebaliknya. Hal ini karena adanya rasa tanggung jawab dari penyusun anggaran untuk ikut mensukseskan pelaksanaan anggaran yang telah mereka susun. Sehingga dengan rasa tanggung jawab yang besar, penyusun anggaran akan terdorong untuk terus meningkatkan kinerjanya.

2. Hasil uji hipotesis kedua menunjukkan hipotesis kedua 
ditolak, yang berarti bahwa komitmen organisasi tidak mampu memoderasi pengaruh partisipasi anggaran terhadap kinerja manajerial. Hal ini karena walaupun seorang pegawai penyusun anggaran memiliki tingkat komitmen organisasi yang tinggi tetapi adanya tekanan dari atasan dan persaingan dari rekan kerja menyebabkan seorang pegawai sulit untuk mengekspresikan rasa kecintaannya terhadap organisasi, sehingga komitmen organisasi tidak dapat memoderasi hubungan antara partisipasi anggaran dengan kinerja manajerial pada SKPD dalam lingkup pemerintah Kabupaten Halmahera Barat.

Sementara itu, beberapa saran yang dapat diberikan sehubungan dengan penelitian ini adalah sebagai berikut:

1. Bagi SKPD dalam lingkup pemerintah Kabupaten Halmahera Barat dapat mempertimbangkan untuk menerapkan sistem partisipasi anggaran sebagai alat bantu manajemen dalam pelaksanaan tugas manajemen yaitu, perencanaan dan pengendalian secara efektif dengan melibatkan faktor perilaku pegawai. Sebab hasil penelitian ini yang membuktikan bahwa adanya partisipasi anggaran dapat meningkatkan kinerja pegawainya. SKPD dalam lingkup pemerintah Kabupaten Halmahera Barat sebaiknya mampu meningkatkan komitmen organisasi pegawainya dan bagi atasan sebaiknya tidak menekan bawahannya dalam melaksanakan tugasnya agar bawahan mampu menunjukkan dan menciptakan sikap komitmen organisasi yang tinggi agar bawahan mampu mendapatkan kenyamanan dalam bekerja serta berkomunikasi. Komitmen organisasi harus tetap dimiliki oleh individu-individu yang terlibat dalam proses penyusunan anggaran karena komitmen organisasi dapat mendorong individu untuk berbuat sesuatu yang dapat menunjang keberhasilan organisasi sesuai dengan tujuan dan lebih mengutamakan kepentingan organisasi.

2. Bagi penelitian selanjutnya respon rate dan useable respon rate sebaiknya ditingkatkan sehingga hasil penelitian lebih representatif. Pengukuran kinerja manajerial juga sebaiknya menggunakan ukuran kinerja keuangan tidak menggunakan self rating scale, sehingga hasil penelitian tidak menimbulkan bias. Selain itu, peneliti selanjutnya perlu menambahkan beberapa variabel dalam hubungannya dengan kinerja manajerial seperti kepuasan kerja, budaya organisasi, asimetri informasi dan lain-lain.

\section{DAFTAR PUSTAKA}

Anthony, R. \& V. Govindarajan. 2005. Management Control System, Jilid I dan II, Terjemahan Kurniawan Tjakrawala dan Krista. Penerbit Salemba Empat: Jakarta.

Bastian, Indra. 2006. Sistem Akuntansi Sektor Publik, Edisi 2. Penerbit Salemba Empat: Jakarta.

Nafarin, M. 2004. Penganggaran Perusahaan, Edisi Revisi. Penerbit Salemba Empat: Jakarta.

Mardiasmo, 2005. Akuntansi Sektor Publik: Penentuan Harga Pelayanan Publik. Yogyakarta.

Mangkunegara, A. A. \& A. Prabu. 2000. Manajemen Sumber Daya Manusia, Cetakan Pertama. PT. Remaja Rosdakarya: Bandung.

Gibson, J. L., John M. I., \& James F. D. 1997. Organisasi dan Manajemen. Penerbit Erlangga: Jakarta.

Garrison, R. H. \& Norren E. W. 2000. Managerial Accounting. Terjemahan Budi Santoso. Penerbit Salemba Empat: Jakarta.

Ghozali, Imam. 2005. Aplikasi Analisis Multivariate dengan 
Program SPSS. Badan Penerbit Universitas Diponegoro: Semarang.

Hafiz, F. W. 2007. Pengaruh Partisipasi Anggaran terhadap Kinerja Manajerial pada PT CAKRA Compact Aluminium Industries. Skripsi. Universitas Sumatera Utara.

Hansen, D. \& R. Mowen. 2012. Management Accounting. Penerbit Salemba Empat: Jakarta.

Ikhsan, A. \& M. Ishak. 2005. Akuntansi Keperilakuan. Penerbit Salemba Empat: Jakarta.

Jogiyanto. $2005 . \quad$ Metodologi Penelitian Bisnis. Badan Penerbit Fakultas Ekonomi Universitas Gajah Mada: Yogyakarta.

Minan, Kresna. 2009. Pengaruh Partisipasi Anggaran terhadap Kinerja Manajerial dengan Komitmen Organisasi sebagai Variabel Moderating pada Perusahaan Manufaktur di Medan. Jurnal Keuangan dan Ekonomi, 1 (1).

Mulyadi. 2001. Akuntansi Manajemen. Penerbit Salemba Empat: Jakarta.

Nordiawan. 2006. Akuntansi Sektor Publik. Penerbit Salemba Empat: Jakarta.

Poerwati, Tjahjaning. 2002. Pengaruh Partisipasi terhadap Kinerja Manajerial: Budaya Organisasi dan Motivasi sebagai Variabel Moderating. Simposium Nasional Akuntansi V, Semarang 5-6 September.

Puspaningsih, Abriyani. 2002. Pengaruh Partisipasi dalam
Penyusunan Anggaran terhadap Kepuasan Kerja dan Kinerja Manajer. JAAI, 6(2).

Robbins, S. P. 2003. Perilaku Organisasi. PT Prenhallindo: Jakarta.

Simamora, H. 2000. Akuntansi: Basis Pengambilan Keputusan, Jilid 1, Cetakan Pertama. Jakarta.

Sekaran, U. 2006. Research Methods for Business, Jilid 1 dan 2, Penerjemah Kwan Men Yon. Penerbit Salemba Empat: Jakarta.

Sugiyono. 2008. Metode Penelitian Bisnis. CV Alfabeta: Bandung.

Sumarno, J. 2005. Pengaruh Komitmen Organisasi dan Gaya Kepemimpinan terhadap Hubungan antara Partisipasi Anggaran dan Kinerja Manajerial. Simposium Nasional Akuntansi VIII Solo, 15-16 September.

Supriyono. 2005. Pengaruh Komitmen Organisasi, Keinginan Sosial, dan Asimetri Informasi terhadap Hubungan antara Partisipasi Penganggaran dengan Kinerja Manajerial. Jurnal Ekonomi dan Bisnis Indonesia, 20 (1).

Terry, G. R. \& L. Rue. 1991. DasarDasar Manajemen. Bumi Aksara: Jakarta.

Welch, G. A., R. W. Hilton, \& P. N. Gordon. 2000. Anggaran, Perencanaan dan Pengawasan Laba, Buku I, Edisi Pertama, Alih Bahasa Purwatiningsih. Penerbit Salemba Empat: Jakarta. 